\title{
SZYMON MIELECKI PAULIŃSKI KOPISTA I BIBLIOFIL Z PRZEŁOMU XVI I XVII WIEKU
}

Zagubione archiwalia i rozszabrowane biblioteki paulinów polskich uważa się za zasadniczy powód nieznajomości historii kultury zakonu do połowy XVII stulecia. Od pewnego jednak czasu dokonuje się różnych prób odtworzenia partykularnych zagadnień polskiej społeczności zakonu oraz przybliżenia biografii niektórych paulinów. Poczyniono już kilka wstępnych analiz dla scharakteryzowania genezy zainteresowań bibliofilskich, kształtowania się skryptorium, rodzimego studium naukowego itp. Prace nie obejmują, rzecz jasna, całoksztaltu problemów z powodu niekompletności źródet i niezwykłego ubóstwa zapisów kronikarskich. Rekonstrukcja dziejów kultury paulinów do połowy XVII wieku prowadzona jest na podstawie analizy przypadkowych najczęściej zapisów, które udaje się łączyć z lapidarnymi nieraz notatkami i równie fragmentarycznymi relacjami wniesionymi na marginesach starodruków lub w aktach transakcji majątkowych. Tą drogą udało się skomponować kilka haseł biograficznych paulińskich kopistów i bibliofilów z przełomu średniowiecza i czasów nowożytnych ${ }^{1}$, wskazać na główne kierunki ich zainteresowań oraz na wartość merytoryczną ich prac wówczas i w chwili obecnej.

W świetle dotychczasowych badań, paulińscy skryptorzy i bibliofile prezentują się jako znakomici kolekcjonerzy książek, autorzy lub kopiści rękopisów (zatroskani o dobry nabór traktatów nie tylko użytecznych w duszpasterstwie), które oblekali w bogate skórzane oprawy w paulińskich introligatorniach zarówno na Jasnej Górze, jak i w krakowskiej Skałce. By nie pozostawać gołosłownym relatorem tej problematyki, wypada wymienić w tym miejscu najpierw prowincjała Marcina z Łubnic $(+1600)$, jednego z największych bibliofilów w zakonie, który ozdobił kilkanaście dzieł bogatymi oprawami, lub polecił skopiować rękopisy użytecznych tekstów ${ }^{2}$; prowincjała Marcina Kamockiego (+1610), który swoje księgi zdobił znakiem herbowym Jelita $^{3}$; o. Szymona Neapolitanusa $(+1621)$, prawdopodobnego kopistę akt jasnogórskich ${ }^{4}$ i użytkownika kilku dzieł, na które wniósł swoje inskrypcje ${ }^{5}$; Andrzeja Żimicjusa vel Zymicjusza ${ }^{6}(+1625)$, autora historii jasnogórskiego obrazu Matki Bożej i kopisty tekstów ${ }^{7}$, autora pierwszego katalogu biblioteki skalecznej ${ }^{8}$, nadto niezwykłego miłośnika książek, których, jak zauważył współczesny mu kronikarz, nie mało się znajduje w bibliotekach ${ }^{9}$; Walentego z Warty $(+1634)$, głośnego polemistę przełomu XVL i XVII w., autora,Promptuarium pauperis concionatoris", spisanego w 1589 r. $^{10}$; i wreszcie o. Szymona Mieleckiego, o którym zamierzam opowiedzieć tutaj nieco szerzej. 
Tytułem uczciwości wspomnieć pragnę o. Mikołaja z Wilkowiecka (+1601), znanego polemistę XVI w. i autora traktatów teologicznych, które doczekały się druku i oceny w literaturze polskiej. Nie zamierzam jednak wyliczać ani rozpisywać się o całokształcie zainteresowań naukowych i bibliofilskich innych paulinów, ponieważ suchą statystykę można uważać za zbędny w tym miejscu balast. Ponadto z przykrością muszę stwierdzić, że przed badaczami jasnogórskiego księgozbioru zamknięto drogę badawczą w wyniku niefortunnej decyzji, która zamieniła kilka lat temu lokal zabytkowej biblioteki na Jasnej Górze na salę konferencyjną dla biskupów i nierzadko dla zwykłych turystów. Dostęp do wielu półek jest obecnie niemożliwy, a ponadto zbyt swobodne zwiedzanie biblioteki spowodowało systematyczne wykradanie dzieł $z$ najniższych futerałów. $Z$ tych względów nie mogłem prześledzić nawet tych egzemplarzy, które znane mi były z dawniej poczynionych wypisów, przed niekorzystną zamianą funkcji lokalu bibliotecznego. Toteż główną, niestety, bazą w obecnych badaniach okazał się księgozbiór archiwalny na Jasnej Górze i biblioteka na Skałce, nietknęta nieszczęślimymi decyzjami lub rękami wandali. W małym zaledwie stopniu mogłem wykorzystać starodruki księgozbioru jasnogórskiego, zdeponowanego poza głównym lokalem bibliotecznym. Na ile więc wyczerpujące są moje tutaj uwagi, nie umiem odpowiedzieć.

\section{Zarys biograficzny o. Szymona Mieleckiego}

Szymon Mielecki urodził się około 1560 r. w Mielcu. Ojcem jego był bliżej nie znany Krzysztof. Czy pochodził on ze szlacheckiej rodziny, która szczyciła się działalnością opata tynieckiego, Mikołaja, syna Jana, urodzonego około $1566 \mathrm{r}^{11}{ }^{11}$, trudno powiedzieć. Wspólne w przyszłości zainteresowania bibliofilskie pozwalają doszukać się pokrewieństwa obu, jakkolwiek dotychczasowe wykresy genealogiczne sprawy tej nie pozwalają wyjaśnić. Sam fakt, że w owym czasie mamy wśród paulinów kilku Mieleckich, pozwala jednak na pewne ciekawe sugestie. Otóż po raz pierwszy spotykamy się z innym mielczaninem Janem, który występuje w $1520 \mathrm{r}$. jako członek konwentu krakowskiego w akcie fundacyjnym Macieja z Miechowa. Rzecz dotyczyła zapisu $100 \mathrm{fl}$. i $30 \mathrm{gr}$. na przebudowę drewnianej partii klasztoru skałecznego $^{12}$. Wiazzała się zatem z kanonikiem krakowskim, Miechowitą, rzekomym fundatorem jego osobistej biblioteki dla klasztoru. Postać Jana zaginęła po latach w pamięci potomnych, a kroniki nie odnotowały nawet roku jego śmierci. Ale około 1585 r. zjawił się chyba inny Jan Myelyecz ${ }^{13}$, o którym wiadomo, że zmarł w $1605 \mathrm{r}$. w Wieruszowie ${ }^{14}$.

Podobnie też w latach siedemdziesiątych XVI stulecia występuje inny mielczanin, Stanislaw, syn Stanisława, który w latach 1579-1580 przyjął jako paulin trzy wyższe święcenia ${ }^{15}$. Po tych datach zginął i on z pola widzenia $w$ zakonie i również nie wiadomo kiedy zmarł. Nie można obecnie rozwiązać problemu, czy wyżej wspomniany Jan był synem Stanisława kasztelana krakowskiego, czy też synostwo to należy się wspomnianemu przed chwilą Stanisławowi. Wiadomo jednak, że sam kasztelan, chorując na nogi, miał doznać cudownego uzdrowienia za przyczyną św. Stanislawa po odwiedzeniu jego grobu na Skałce. Rzecz działa się w 1518 r., kiedy uczczono to wydarzenie jakimś pomnikiem lub znaczącym wotum ${ }^{16}$. 
Raz zadzierzgnięte więzy mielczan z zakonem utrwalały się przez kilka co najmniej pokoleń. Odnosi się to do bliżej nieokreślonego zapisu Mieleckich dla kościola i klasztoru w Beszowej na wsi Rzędzianowice k. Mielca. Zachował się nawet pokaźny poszyt aktowy, z którego wynika, że w 1645 r. członkowie rodu Mieleckich na czele z Zofią ze Stanisławic, wdową po Stanisławie Mieleckim domagali się prawnego uregulowania i wyjaśnienia zapisu ${ }^{17}$.

Wstapienie zatem Szymona Mieleckiego do paulinów nie pozbawione było głębszych podstaw i sympatii familijnych lub co najmniej regionalnych. Daty jego wstąpienia do paulinów nie znamy. Znamy natomiast daty trzech święceń, dzięki którym wolno przypuścić, że w habit pauliński został obleczony około 1575 r. Studiował niewątpliwie na Skałce w Krakowie, gdzie otrzymał trzy wyższe święcenia. I tak w dniu 9 czerwca 1582 r. przyjął święcenia subdiakonatu, 26 marca 1583 r. diakonatu, a 22 grudnia 1584 r. kapłańskie. Konsekratorem był, jak się wydaje, bp Piotr Myszkowski, a miejscem święceń katedra na Wawelu ${ }^{18}$.

I tyle na razie szczegółów udało się znaleźć odnośnie do jego życia we wczesnej młodości, po wstapieniu do paulinów. Z czasów późniejszych brak dokładniejszych wiadomości o jego pracach. Wiadomo jednak, że od $1590 \mathrm{r}$. występował w konwencie krakowskim, prawdopodobnie w charakterze kaznodziei. $Z$ dużym prawdopodobieństwem można mu przypisać spis paramentów liturgicznych kościoła skałecznego, sporządzony około $1593 \mathrm{r}^{19}{ }^{19}$. W tym też roku spotykamy go na Jasnej Górze, gdzie pełnił najprawdopodobniej obowiązki kaznodziei. Pracowal nadto w skryptorium na usługach wspomnianego wyżej prowincjała Marcina z Łubnic i to zarówno w domu krakowskim, jak i jasnogórskim. Pod jego kierunkiem zapoczątkował, lub kontynuował spisywanie kilku kodeksów, które zostaną omówione niżej. Ponadto pełnił w domu jasnogórskim funkcje sekretarza lub bibliotekarza. $\mathrm{Na}$ jednym, znanym mi kodeksie wpisal własną ręką znak proweniencyjny $^{20}$. W połowie $1612 \mathrm{r}$. znalazł się w klasztorze głogówieckim, gdzie $w$ dniu 13 sierpnia zastała go śmierć ${ }^{21}$.

Powyższa niespójna biografia o. Szymona Mieleckiego byłaby jeszcze bardziej spłaszczona, gdyby nie jego twórczość pisarska jako kopisty, wynikająca z obowiązków kaznodziei oraz z zamiłowania do tworzenia dzieł w celu utrwalenia faktów historycznych. Pełnego dorobku jego prac nie sposób dzisiaj ustalić z powodów, o których wspomniałem wyżej, przypadkowo zaś odkryte przed laty kodeksy oraz interwencyjne wpisy nie dają jeszcze pełnego obrazu jego bibliofilskich zainteresowań i piśmienniczej twórczości.

\section{Twórczość kopistyczna i bibliofilska Szymona Mieleckiego}

Twórczość kopistyczna i pisarska o. Mieleckiego była wynikiem zapotrzebowania na dzieła użyteczne w pracy duszpasterskiej oraz konieczności zachowania pewnych wartości duchowych w życiu rodziny paulińskiej. Twórczość tę rozwijali od dawna wytrawni kopiści tej miary co Wacław Żydek i wybijający się historycy paulińscy: Mikolaj z Wilkowiecka, Andrzej Żimicjus i inni. Nad całością prac czuwał jednak prowincjał Marcin z Łubnic, który w świetle znanych mi przykładów starał się o sprowadzanie do bibliotek klasztornych możliwie najlepszych dziet teologicz- 
nych, oprawiał stare kodeksy w nowe okładki, zlecał swoim podwładnym dopisywanie brakujących rozdziałów itd.

Tak postapił w przypadku znanego już w polskiej literaturze kodeksu reguł, zwanego „katenatem”, do którego o. Mielecki dopisał pierwszą brakującą kartę oraz na końcu cztery dokumenty, dotyczace prawodawstwa zakonu z lat 1484-1574 ${ }^{22}$.

Kodeks reguł już w końcu XVI stulecia był bardzo zniszczony, zresztą niełatwy także do czytania, gdyż większość ojców przyzwyczaiła się do czytelnego, renesansowego duktu pisma. $W$ tej sytuacji zlecono, jak się wydaje, o. Mieleckiemu skopiowanie nowego kodeksu, czego dokonał w sposób mistrzowski. Spisał go na pergaminie pięknym renesansowym duktem w dwóch kolumnach. Tekst Reguły ozdobił czterema piórkowymi miniaturami, a tytuły zaznaczył cynobrowym lub zielonym tuszem ${ }^{23}$. Rękopis oprawiony został w białą skórę, na której wytłoczono pięć rzędów radełkowych tłoków ułożonych w kształcie prostokątnej ramki, z których glówne radelko podzielone zostało na małe segmenty $z$ wizerunkami Ewangelistów. W lustrze okładki wyciśnięta została postać Chrystusa na krzyżu na tle monogramu IHS. Na okładce tylnej wzór graficzny skomponowano analogicznie, z wyjątkiem plakiety z wyobrażeniem króla Dawida. Na przedniej okładce wyciśnięty został tytuł kodeksu, a na tylnej data roczna 1593. Styl tej oprawy powtarza się w licznych kodeksach jasnogórskich i skałecznych ${ }^{24}$ i świadczy o dużym smaku artystycznym Marcina z Łubnic jako niewątpliwego mecenasa tych opraw.

Jest bardzo prawdopodobne, że o. Mielecki był kopistą siedmiu znanych obecnie dokumentów dotyczących Jasnej Góry od połowy XVI stulecia po czasy sobie współczesne oraz 72 mirakulów, spisanych ze starych kodeksów, jak również na bieżąco podawanych w zakrystii sanktuarium ${ }^{25}$. Warto w tym miejscu zauważyć, że dzieło, w którym znalazły się powyższe wpisy zapoczątkował również o. Marcin $z$ Łubnic. Zatytułował je jako księgę mirakulów i historii kultu Matki Bożej. Jako pierwszy wprowadził do niego najważniejsze wówczas opisy z dziejów klasztoru wspomniany o. Andrzej Żimicjus, oddając następnie pole pracy o. Mieleckiemu. Księga ta wymaga szczegółowej analizy porównawczej, jest bowiem doskonałym przykładem kultury umysłowej paulinów i ilustracją ich troski o utrwalenie możliwie pełnej dokumentacji dziejów kultu maryjnego na Jasnej Górze.

Tym trzem dziełom patronował o. Marcin z Łubnic, który narzucił im szatę zewnętrznąi i uwiecznił się na okładce swoimi inskrypcjami. Nie wiadomo kto był ich introligatorem. Z całą pewnością można jednak powiedzieć, że zostały wykonane na Jasnej Górze lub na Skałce przez mistrza, który posługiwał się dość dużą ilością tych samych radełek i plakietek ${ }^{26}$, otaczanych różnymi hasłami i tekstami, świadomie lub pomyłkowo nawet $z$ błędami. Przykładem może tu być okładka kodeksu należącego niegdyś do przeora krakowskiego o. Marcina Kamockiego, datowanego na rok 1593 i przechowywanego w bibliotece skałecznej pod sygnaturą IX B 1, oraz okładka we wspomnianym kodeksie reguł, znajdującym się w archiwum jasnogórskim pod sygn. 899.

W cieniu lub obok znakomitego bezsprzecznie bibliofila, jakim był Marcin z Łubnic, wyrastał nie mniej znakomity i kochający ksiażki o. Mielecki. Pracował on nie tylko nad utrwaleniem tekstów prawnych lub kopiowaniem zniszczonych, ale z niezwykłą pieczołowitością ratował rozsypujące się stare kodeksy, które w innych 
domach najczęściej wrzucano do pieca. W obecnym stanie badań jemu przypisać należy uzupełnienia w brewiarzu paulińskim, wydanym w Wenecji w $1514 \mathrm{r}$. Dopisal w nim dwanaście brakujących w środkowej partii kartek, wnosząc tekst w dwóch kolumnach maleńkimi literkami zbliżonymi do druku, a całość ozdobił cynobrowymi wyjaśnieniami. Na końcu dodał teksty brewiarzowe o św. Stanisławie, których brewiarz zakonny nie posiadał ${ }^{27}$. Czy brewiarz ten należał do księgozbioru o. Mieleckiego nie wiadomo. Wiadomo natomiast, że oprawiony został około $1590 \mathrm{r}$. w okładki opisane wyżej, a więc w pracowni, której patronował Marcin z Łubnic.

Mniejsze interwencje, niemniej charakterystyczne, znajdują się w mszale paulińskim z 1537 r., do którego o. Mielecki wprowadzit formularz mszalny o św. Stanisławie. I tym razem starał się o upodobnienie swego pisma do druku, tekst wpisał w dwóch kolumnach, a rubryki wyjaśniające zaznaczył cynobrem ${ }^{28}$. Czy i on należał do jego osobistego księgozbioru odpowiedzieć nie sposób. Okładka, w którą został mszał obleczony zdaje się wskazywać, że rekonstrukcji dzieła patronowal także Marcin z Łubnic.

Inaczej natomiast prezentują się dzieła, które zainicjowane i sfinalizowane zostały przez o. Mieleckiego. W obecnym stanie badań znamy ich tylko trzy, oprócz dziet, które należały do jego księgozbioru. Najpierw chciałbym zauważyć, że udało się odnaleźć znakomite mowy Adama Bigi, dominikanina, zakupione przez bliżej nie znanego Stanisława Paionawiego. Około $1590 \mathrm{r}$. posiadaczem kodeksu stał się o. Mielecki, który dzieło oprawił w skórzane okładki, nadając im piękną barokową szatę, która stała się wzorem dla wszystkich innych dzieł w jego księgozbiorze. Tu po raz pierwszy spotykamy się bowiem z ciemnobrunatną skórkową oprawą, na której introligator wycisnął $z$ jednej strony duży medalion o tematyce adoracji krzyża, a z drugiej scenę Ukoronowania Matki Bożej. W narożach i na bokach umieścił nadto drobne ornamenty zdobnicze, na przedniej okładce wytłoczył tytuł, na tylnej zaś pełne imię i nazwisko właściciela ${ }^{29}$.

"Sermones" Adama Bigi, a sądzić można, że i kilka innych dzieł również, wprowadzają nas w krąg osobistych zainteresowań i funkcji, które wypadło pełnić o. Mieleckiemu w ciągu całego życia u paulinów. Wszystko zdaje się wskazywać na to, że kopiował kazania z różnych autorów, być może kompilował je według własnego przemyślenia, dzięki czemu zrodziły się pod jego piórem trzy a może cztery kodeksy homilii na wszystkie niedziele i święta całego roku. Niestety, zachował się jedynie jeden tom przemówień letnich i drugi o świętych. Rękopis pierwszy znajduje się na Jasnej Górze, a drugi w rękach prywatnych, o czym będzie mowa niżej.

Pierwszy, jasnogórski kodeks homilii, zatytułowany „Postilla Catholica pars aestiva", spisany został na papierze formatu $23 \times 16,5 \mathrm{~cm}$, zawiera kart 279 i 3 nieliczbowane. Teksty homilii spisane zostahy brunatnym atramentem $w$ ramach zakreślonych marginesów, poza którymi na linii pionowej wniósł o. Mielecki notki do źródet. Homilie spisane zostały duktem czytelnym, ale bez zbytniej troski o stylizację lub elegancję. Rękopis oprawiony został $w$ ciemnobrunatną skórę, na której w centralnym polu wyciśnięto barokową plakietkę $z$ dużym krzyżem, pod spodem kielich, obok dwa delikatne skręty liści, na które narzucony został przytlaczający monogram IHS. Wokół powyższych symboli biegnie napis OMNIS ENIM 
QUICUMQUE VOCAVERIT NOMEN DOMINI SALVUS ERIT (Ro[manos]10). Całość plakiety zdobią rozchodzące się od środka duże sfałdowane promienie zamknięte dodatkowym grubym radełkiem. Ponadto obie okładki wieńczy wąskie gotyckie radełko $z$ wzorem delikatnego listowia, wyciśnięte na skrajach czterech boków. Oprócz nich introligator dodał cztery renesansowe narożne ozdoby, a także dwanaście wzorów kwiatowych i jedenaście gwiazdek. Nad plakietką wytłoczył pierwszą część tytułu POSTILLA CATHOLICA, a pod plakietą PARS AESTIVALIS. Podobny układ narzucił na okładce tylnej, tym razem jednak na plakietce znalazło się przedstawienie Matki Bożej Bolesnej z siedmioma mieczami, a wokół niej ten sam napis co wyżej: OMNIS ENIM QUICUMQUE... Nad plakietką wytłoczono nazwisko i imię autora dzieła: FRATER SIMON MIELETIUS.

Rękopis powyższy zawiera homilie niedzielne i świąteczne w języku polskim, począwszy od 1 niedzieli Adwentu do 6 niedzieli po Trzech Królach. Właściwy byłby więc tytuł „pars hiemalis”, niemniej w omawianym kodeksie figuruje określenie „pars aestivalis" - może omyłkowo włączony do tej partii tekstu? Kodeks nie posiada obecnie karty tytułowej i zapowiedzi pierwszej homilii. W następnych podaje, że teksty zaczerpnął z kazań Piotra Skargi, Orozjusza, Jakuba z Voraginy i innych. Autor korzystał z homilii bezpośrednio na ambonie jasnogórskiej i w innych domach, o czym poinformował na pierwszej koszulce, a także licznymi podkreśleniami czerwoną kredką. Studium nad wartością merytoryczną rękopisu byłoby bardzo pożyteczne, tym więcej, że jest to wzorcowy i poniekąd unikalny przekaz kaznodziejski ostatnich lat XVI stulecia. Dowodzi tego znamienny łaciński wpis, że dzieło to jest dla biblioteki jasnogórskiej prawdziwą ozdobą, a zamiana go na inne dzieło, lub przywłaszczenie, spowoduje przekleństwo ${ }^{30}$.

Drugi sygnowany rękopis pt. Postilla Catholica de sanctis, spisany został przez Mieleckiego na papierze różnej proweniencji. Podzielony został na dwie części, w pierwszej skopiowano kazania o świętych i na niedziele, w drugiej zaś o Matce Bożej. W obecnym stanie kodeks nie posiada karty tytułowej, ponadto wyrwano $z$ niego znaki proweniencyjne. Należał do bliżej nieznanej biblioteki paulinów i oznaczony był sygnaturą IV C 7, potem 119. W niewyjaśnionych okolicznościach dostał się w ręce pamiętnikarza Królestwa Polskiego, Wojciecha Dobieckiego (+1862), a później w kragg rodziny Chrzanowskich w Moroczynie. Obecnie jest w posiadaniu krakowskiego literata i historyka sztuki Tadeusza Chrzanowskiego ${ }^{31}$.

„Postilla de sanctis” posiada znak autorski na karcie cz. II: (...) conscriptae per fratrem Simonem Mieletium(...) 1599. Posiada także ślepe tłoki na tylnej okładce: FRATER SIMON MIELETIUS 1600. Pierwsza część zawiera 165, druga 93 karty formatu $20 \times 15,5 \mathrm{~cm}$. Część I homilii o świętych spisana została bardzo niestarannym pismem z licznymi skreśleniami, górnymi glosami, lub nakładaniem się nowych słów na stary zapis. Część II, zaczynająca się od nowej paginacji, spisana została bardzo starannie, duktem równym, kaligraficznym i bez żadnych poprawek. Autor ozdobił tę część dwukolorowymi inicjałami, niektóre karty zakreślił delikatnym, ozdobnym marginesem, na innych wprowadził rysunki małych rączek jako zwiastuny nowych treści. Na początku tej części wystylizował ozdobny spis treści, a następnie barokowy tytuł, zatłoczony wzorami graficznymi i wymyślnymi symbolami. 
Na końcu dzieła, od karty 77 autor dorzucił pięć różnych kazań, w tym jedno w języku polskim, a drugie makaroniczne (łacińsko-polskie), spisane znów niedbale, nawet poza ramkami marginesów, co jednoznacznie zdaje się wskazywać, że kazania te powstały jako materiał na ambonę, a następnie dołączone zostały przez autora do obecnego kodeksu.

Zawartość treściowa „Postylli de sanctis” jest obmyślana według porządku roku kościelnego, począwszy od 1 niedzieli Adwentu aż po ostatnią niedzielę Zesłania Ducha Świętego. Nie odpowiada więc w pełni tytułowi na okładce, bowiem kazania o świętych wymieszane są z homiliami niedzielnymi. Czy usprawiedliwiają ten układ opuszczenia kilkunastu homilii zwykłych po niedzieli Wielkanocnej trudno powiedzieć, gdyż nie znamy układu w innych nie zachowanych kodeksach. Porzadek treściowy zdaje się być dość przypadkowy. Z początku autor cytował zaledwie jeden werset biblijny, jako motto homilii, później, szczególnie w homiliach maryjnych, zagubił klasyczny styl postylli, przepisał kilka pelnych perykop ewangelicznych na poszczególne niedziele i święta, w tym aż trzy ewangelie w języku polskim. Także homilie maryjne na temat dziewięciu tajemnic życia Matki Bożej jedne skopiował, czy opracowal, w trzech wersjach łacińskich i polskich, inne znów tylko pojedynczo w języku łacińskim.

$Z$ jakich wzorów homiletycznych korzystał o. Mielecki nie sposób na razie odpowiedzieć, choć dla badaczy kaznodziejstwa polskiego odpowiedź nie stanowiłaby zapewne większej trudności. Nie wydaje się jednak, by główny zrąb homilii był osobistym wytworem myślowym o. Mieleckiego. Cytuje on na marginesach autorów, na których się powołuje, ale czy odnośniki te nie zostały przeniesione z innych wzorców kaznodziejskich na razie nie sposób odpowiedzieć. W każdym razie „Postilla de sanctis” w obecnym stanie badań jest bardzo ważnym przekazem kultury paulińskich kaznodziejów, a wklad o. Mieleckiego jako homilety i nauczyciela prawd, w tym treści maryjnych, w szczególności.

Jest ponadto o. Mielecki autorem innego dzieła, które stawia go w szeregu wybitnych liturgistów i miłośników kultury mniszej. Dał temu już przykład we wspomnianych wyżej ingerencjach mszalnych i brewiarzowych. Uratowal w obu przypadkach dwa zniszczone kodeksy, które w 1600 r., w wyniku reformy liturgicznej generała Szymona Bratulicia (+1611) stały się jedynie księgami historycznymi. Decyzja jego podyktowana została koniecznością. Oto $w$ klasztorach bywały zaledwie pojedyncze mszały zakonne i do tego nierzadko bardzo zniszczone. Przykładowo warto wspomnieć, że w $1584 \mathrm{r}$. w konwencie brdowskim były zaledwie dwa mszaly ${ }^{32}$, a na Skałce w Krakowie trzy, z których jeden zabrał na Węgry wspomniany przed chwilą 0 . Bratulić ${ }^{33}$. Znacznie gorzej przedstawial się stan innych ksiąg liturgicznych, zwłaszcza brewiarzy i kancjonałów.

Ojciec Mielecki próbował, jak się wydaje, zaradzić tym kłopotom. W $1591 \mathrm{r}$. opracował pod wpływem o. Marcina z Łubnic radko spotykaną księgę liturgiczną o charakterze brewiarzowym. Nazwal ją "Collectarium Romanum cum Callendario Gregoriano". Jest to bardzo interesujący i wyjątkowy rękopis spisany na papierze formatu $30,3 \times 20,4 \mathrm{~cm}$. Spisany w dwóch kolorach czarnym tuszem z licznymi cynobrowymi rubrykami. Oprawiony został $w$ ciemnobrunatną skórę o wzorze graficznym jak w poprzednich dwóch kodeksach. Na okładce przedniej wyciśnięta 
została plakieta Ukoronowania Matki Bożej w obłokach nad księżycem z obecnością dwóch aniołów. Plakietę tę spotykamy w szeregu dzieł skałecznych i jasnogórskich, m.in. na okładce „Missale Romanum" czy też wspomnianych już „Sermones" Adama Bigi, a należących do księgozbioru o. Mieleckiego ${ }^{34}$. U góry i dołu tej plakiety wyttoczono majuskulny tytuł COLLECTARIUM ROMANUM. CLARI MONTIS ANNO DOMINI 1591. Na okładce tylnej zamieszczono tej samej wielkości plakietę ze sceną Ukrzyżowania i postaciami Matki Bożej oraz św. Jana. Wokół tej sceny biegnie napis CHRISTUS FACTUS EST PRO NOBIS OBEDIENS USQUE AD MORTEM AUTEM CRUCIS. PHI 2 [7-8]. Nad plakietą wniósł introligator inskrypcję o. Mieleckiego: F.S.M.

„Collectarium Romanum”, nie posiadające dotąd właściwego odpowiednika wśród ksiag liturgicznych, wymaga bliższego wyjaśnienia. Zawiera przede wszystkim modlitwy, antyfony i responsoria brewiarzowe na święta kościelne i własne zakonne. Całość dzieła autor podzielił według następującego porządku:

1. Karta tytułowa ze znamiennym wyjaśnieniem na jej odwrociu o spisaniu dzieła na Skałce w Krakowie z pozwoleniem i błogosławieństwem o. Marcina z Łubnic.

2. Spis treści.

3. Kalendarz gregoriański z zaznaczeniem świąt paulińskich.

4. Modlitwy brewiarzowe zw. Proprium de Tempore (k. 29), począwszy od 1 niedzieli Adwentu, a więc od antyfony, nieszporów, godzin mniejszych i komplety z paulińskim Confiteor. Wśród tekstów znalazły się różne litanie i modlitwy, zw. do niedawna preceskami, nadto modlitwy i błogosławieństwa maryjne jako odrębny poddział (k. 83).

5. Modlitwy o świętych (k. 91) z odrębnym poddziałem dla apostołów (k. 143).

6. Modlitwy do Najśw. Panny oraz Officium Parvum (k. 155).

7. Modlitwy różne, m.in. za zmarłych, o Krzyżu Świętym, o pogodę, do św. Pawła Pustelnika, do św. Stanisława bpa itp.

8. Modlitwy zalecane przez papieża Sylwestra (k. 173).

Poszczególne części "Collectarium" posiadają późnogotyckie tytuły, ozdobione skrętami dowolnych wzorów oraz ciężkimi łodyżkami kwiecia na marginesach. W czarne i cynobrowe liście o. Mielecki trzykrotnie wkomponował inskrypcję swego imienia i nazwiska (k. 29, 93, 156) oraz dwukrotnie rok spisania 1590 (k. 29, 91) i raz rok 1591 (k. 156). Szczególnie charakterystyczne w „Collectarium” są różnorakie wyjaśnienia o pożytku samego dzieła, zaczerpnięte z Pisma Świętego, które prowadzą do zasadniczego celu, jakim jest "in laudem Dei omnipotenti et betae gloriosissimae Deiparae semperque Virginis Mariae omnibus sanctis" (koniec tytułu) ${ }^{35}$.

$\mathrm{Na}$ ile "Collectarium" miało jakieś zastosowanie w paulińskiej literaturze w przeddzień kasaty rubryk liturgicznych zakonu, trudno odpowiedzieć. Mogło służyć za praktyczną księgę chórową dla kantora lub dla hebdomadarza prowadzącego śpiew liturgiczny. Obecnie rękopis "Collectarium" jest bardzo zniszczony z powodu nałożenia grubej warstwy tuszu, który wygryzł całe partie ozdób, a nawet spowodował rozsypanie niektórych kart. Mimo tego zniszczenia "Collectarium" budzi podziw z powodu pięknej szaty, pomysłowych rozwiązań artystycznych między modlitwami i oryginalnych rozwiazzań w układzie treści, wielości różnych tekstów, które albo już ginęly w codziennym użytku, albo też pielęgnowane były ze szcze- 
gólnym sentymentem $w$ kręgu samych paulinów. Ponieważ nie znamy $w$ tym okresie podobnego liturgicznego wzoru, o. Mieleckiego można uważać za znakomitego, lecz odosobnionego liturgistę epoki potrydenckiej. Nie mógł on odegrać czołowej roli w utrzymaniu paulińskiej liturgii, ponieważ systematycznie taniejące księgi Kościoła Powszechnego wypierały zniszczone propria zakonu, a prace o. Mieleckiego na rzecz ich utrzymania okazały się spóźnione i chyba nie dostrzeżone w kręgu decydentów zakonu. Decyzja o zarzuceniu paulińskiej liturgii sprawiła, że zagubiono zasadniczy kościec duchowości zakonu. Znaleźli się jednak ludzie, którzy uratowali po latach kilka własnych melodii, formularzy mszalnych, hymnów i antyfon, które weszły do odrębnych ksiagg liturgicznych. Tymczasem z biegiem lat, gdy "moderatorzy" zakonu z predylekcją powielali niespójne u paulinów modele obcych zgromadzen, to $w X X$ wieku, w dobie reform posoborowych, $z$ powodu nieznajomości własnej przeszłości, zniszczyli tamte historyczne i pieczołowicie podtrzymywane relikty paulińskiej tożsamości w dziale liturgii, a także i różnorakich form zachowawczych. Prace o. Szymona Mieleckiego są świadectwem tych przemian i jego osobistego zaangażowania na rzecz uratowania paulińskich odrębności kulturowych.

\section{Przypisy}

' Przedstawiłem ich biogramy na łamach pracy „Kopiarze dokumentów zakonu paulinów w Polsce do polowy XVII wieku”, "Archiwa, Biblioteki i Muzea Kościelne" 1979, nr 34-35.

${ }^{2}$ Zapoczątkował on pierwszy tom kronik lask i kultu Matki Bożej Jasnogórskiej, AJG 2096, a także inne, przechowywane w archiwum jasnogórskim (AJG): 2738, III 24; zakupil także konkordancję Pisma św. dla biblioteki jasnogórskiej (BJG), przechowywaną obecnie w bibliotece skalecznej (BSk) I C 2.

${ }^{3}$ Osoba Marcina Kamockiego zasługuje na osobne studium, jak również jego starodruk oprawiony w brązową skórę $\mathbf{z}$ inskrypcją i datą 1593. BSk IX B 1.

${ }^{4}$ Miraculorum B.V. Monasterii Częstochoviensis, tomus primus, AJG 2096, k. 4v-8v.

${ }^{5}$ M.in. na okładce dziela św. Wincentego: Sermones aestivales, BJG, b. sygn.

${ }^{6}$ Autor podpisywał się raz Żimicius (BJG V G 25, AJG 1346 s. 67), lub Zymicjusz (Skarbnica Kościoła, zob. niżej).

${ }^{7}$ A. Zymicjusz, Skarbnica Kościoła Jasnej Góry... Kraków 1618. Zapisy jego ręką o sprawach jasnogórskich i paulińskich są w AJG 2096, k. 1-4v, 13v-15v.

${ }^{8}$ Regestrum argenti, vexillorum... et librorum bibliothecae, 1582-1672, ASk 169, s. 99-100.

${ }^{9}$ Catalogus Fratrum Defunctorum, AJG 77, s. 346-347.

${ }^{10}$ Promptuarium pauperis concionatoris in laudem... Dei, 1589, AJG I 9.

$"$ Por. P. Sczaniecki, Katalog opatów tynieckich. „Nasza Przeszłość" 49: 1978, s. 146.

12 Dokument nosi date 27 X 1520 r. Acta Episcopalia, t. 7, k. 83-83v, Arch. Metr. w Krakowie. Zob. Wypisy źródłowe do dziejów Wawelu. Z archiwaliów kapitulnych i kurialnych krakowskich 1516-1525. Wybral i opracowal Bolesław Przybyszewski, Kraków 1970, s. 134.

${ }^{13}$ Jasnogórski rękopis Regestrum Confraternitatis Fratrum S. Pauli Primi Eremitae z lat 1517-1613. Przygotowal do druku J. Zbudniewek, „Studia Claromontana" 6: 1985, s. 258.

${ }^{14}$ AJG 77, s. 336-337.

${ }^{15}$ Paulini XVI-XVIII wieku w krakowskich i częstochowskich wykazach święceń. Oprac. J. Kracik, „Studia Claromontana" 5: 1984, s. 315. 
${ }^{16}$ K Niesiecki, Herbarz polski. T. 6, Lipsk 1841 , s. 393.

17 Pełny rejestr aktowy tych dokumentów podaje Liber documentorum ecclesiarum parochialium Mielec et Beszowa. Arch. Diec. w Kielcach, sygn. 84.

${ }^{18}$ Paulini XVI-XVIII wieku, s. 315.

${ }^{19}$ ASk 169 , s. 9-10.

${ }^{20}$ Valerii Maximi dictorum et factorum memorabilium libri novem, BJG XIII D 5-5e.

${ }^{21}$ AJG 77, s. 38-39.

22 Szerzej o tym kodeksie, por. J. Zbudniewek, Kodeks Regut Pauliniskich zwany "Katenatem" na tle kultury ksiażki w zakonie paulinów. [W:] Z badań nad polskimi księgozbiorami historycznymi, pod red. B. Bieŕkowskiej. Z. 4. Warszawa 1980, s. 107-133.

${ }^{23}$ Regula Sancti Augustini, 1593, AJG 899, s. 1-95. Tekst od s. 96 zawiera dekrety z 1624 r. spisane inną ręką, a od s. 97 ręką o. Piotra Lasoty.

${ }^{24} \mathrm{~Np}$. na starodruku Monita Sacra, oprawionym w 1616 r., BJG IV G 12, oraz na kodeksie skakecznym: Prima pars Summae S. Thomae, BSk IX B 1.

${ }^{25}$ AJG 2096, k. 3-4, 8v-14v, 16-18, 52-52v, 63-84.

${ }^{26}$ Chodzi glównie o plakiety, które opisane zostały poniżej przy analizie Collectarium Romanum. Tutaj należy dodać nadto oprawę Missale Romanum (BSk II B 1 1928) z wytloczoną inskrypcją F.S.T. (być może frater Stanislaus Trzemeszno, zm. 1626) z glosami o. Walentego z Warty, wykonana z wykorzystaniem starych plakietek lecz i przy zastosowaniu bardzo bogatych dekoracyjnie i nieznanych dotąd radetek.

${ }^{27}$ Brevarium Fratrum Heremitarum S. Pauli, BJG X H 2.

${ }^{28}$ Missale S. Pauli I Eremitae. Venetii 1537, BJG I F 7/3.

${ }^{29}$ A. Bige, Sermones Dominicales, BJG IV F 9. Do biblioteki jasnogórskiej trafił on w 1620 r. po śmierci Szymona Mieleckiego.

30 Postilla Catholica pars aestivalis, AJG II 51.

${ }^{31}$ Kodeks ten udostępnił mi do badań prof. T. Chrzanowski za co serdecznie w tym miejscu mu dziękuję. W ASk 20, 21 znajdują się jego mikrofilmy.

${ }^{32}$ Monumenta historica dioecesos Wladislaviensis. T. 22, Wladislaviae 1903, s. 126.

${ }^{33}$ ASk 169 , s. 3.

${ }^{34}$ Missale Romanum, BSK II b 1, 1928; A. Bige, Sermones, BJG IV F 9 . Motyw ten w pomniejszeniu znajduje się na współczesnych tym czasom okładkach, m.in. w BJG V G 26, oraz na okładce dzieła B. Vincenti: Sermones Hyemalis, 1583, BJG, b. sygn.

${ }^{35}$ Collectarium Romanum cum Callendario Gregoriano, AJG III 24. 